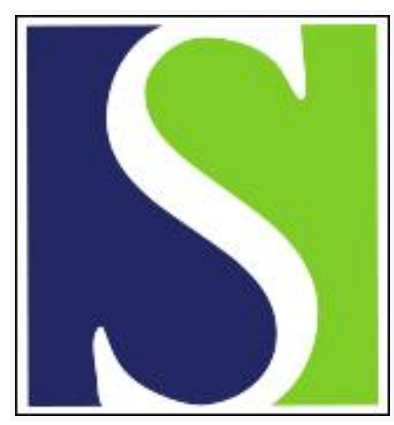

Scand J Work Environ Health 1989;15(6):387-394

https://doi.org/10.5271/sjweh.1834

Issue date: Dec 1989

Incidence of cancer among welders and other workers in a Norwegian shipyard.

by Melkild A, Langard S, Andersen A, Tonnessen JN

Affiliation: Telemark Central Hospital, Department of Occupational Medicine, Porsgrunn, Norway.

This article in PubMed: www.ncbi.nlm.nih.gov/pubmed/2617255

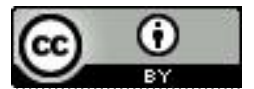




\title{
Incidence of cancer among welders and other workers in a Norwegian shipyard
}

\author{
by Anne Melkild, MD, ${ }^{1}$ Sverre Langård, MD, MSc, ${ }^{1}$ Aage Andersen, ${ }^{2}$ \\ Johan N Stray Tønnessen, MD ${ }^{3}$
}

\begin{abstract}
MELKILD A, LANGÅRD S, ANDERSEN A, STRAY TØNNESSEN JN. Incidence of cancer among welders and other workers in a Norwegian shipyard. Scand J Work Environ Health 1989;15:387-394. The incidence of cancer among 4778 male shipyard workers, including 783 mild steel welders, was investigated in a historical cohort study. The workers had been employed for at least three months between 1 January 1946 and 31 March 1977. The incidence of cancer was observed from 1 January 1953 through 1986. The loss during follow-up was only $0.9 \%$. There were 53 observed cases of lung cancer in the whole cohort versus 31.3 expected on the basis of the national rates for men. There was an increased incidence of lung cancer among the welders, with seven observed cases versus 3.2 expected. Twenty-two cases of bladder cancer were observed versus 15.2 expected. Two malignant mesotheliomas had occurred $(0.7 \mathrm{ex}-$ pected). Smoking was likely to be a confounder in the present study. Due to concomitant exposure to asbestos, the results are inconclusive concerning the possible relationship between exposure to welding fumes and lung cancer.
\end{abstract}

Key terms: asbestos, bladder cancer, cohort study, lung cancer, welding.

There has been concern for some years about a possible excess of cancer, especially lung cancer, among welders. Several epidemiologic studies indicate that welders exhibit a higher incidence of lung cancer than selected reference populations $(1-9)$, while others have not reproduced these findings $(10,11)$. Asbestos and smoking have been possible confounders in most of the studies (12). It has, however, been suggested that welders in general exhibit an approximately $30 \%$ greater incidence of lung cancer (than the nonwelding population) that cannot be ascribed to smoking or other occupational hazards (13).

Fumes from stainless steel welding are mutagenic in bacteria tests (14) and cause transformation in mammalian cell transformation assays (15). Fumes from mild steel welding have been found to be inactive in these test systems (15). On the basis of this background, it has been suggested that the observed excess of lung cancer among welders can be ascribed to highrisk subgroups who weld stainless steel and are thus exposed to hexavalent chromium (16). If this suggestion is correct, one could expect a cohort of mild steel welders to exhibit only a moderate or no excess of lung cancer.

The purpose of the present study was to investigate the incidence of cancer among welders and other ship-

\footnotetext{
1 Telemark Central Hospital, Department of Occupational Medicine, Porsgrunn, Norway.

2 The Cancer Registry of Norway, Montebello, Oslo, Norway.

${ }^{3}$ Health Department, Rosenberg Verft, Stavanger, Norway.
}

Reprint requests to: Dr S Langård, Telemark Central Hospital, Department of Occupational Medicine, N-3900 Porsgrunn, Norway. yard workers. The welders were all shipyard workers who had mainly welded mild steel. The recognized excess of lung cancer in the shipbuilding industry is generally attributed to asbestos exposure $(9,17-22)$. Hence it was considered important to include contemporary workers at the shipyard, not only for a possibility to study their incidence of cancer as such, but also to serve as internal reference groups for the welders.

\section{Background information}

\section{Shipbuilding}

The study was conducted at a shipyard located on the southwestern coast of Norway. The yard was first established in 1896 . Initially the main products were fishing boats and steamboilers. The company expanded rapidly after World War II, partly due to a large amount of repair work. A total of 953 ships were repaired from 1947 to 1951 . Having produced mainly freighters after the war, the shipyard specialized in building oil tankers from 1950 onwards. From 1971 to 1979 the yard's main product was gas carriers. Since 1978 the major products have been large offshore structures for the North Sea oil industry.

New ships were built in sections. Steel plates and pipes first entered the workshops for cutting, welding, and assembly work. The assemblies were then transported to the docks for completion, including fitting out and insulation. Repair work was performed at a separate dock, but parts, including asbestos-covered pipes, were transported to the workshops for further handling. The main workshops at present are the plate shop covering $10000 \mathrm{~m}^{2}$, the welding shop $\left(9000 \mathrm{~m}^{2}\right)$, 
and the pipe shop $\left(3700 \mathrm{~m}^{2}\right)$. The yard has a separate machine shop of $2000 \mathrm{~m}^{2}$ and sandblasting and painting halls.

\section{Welding}

Only a few workers welded before 1940, and riveting and welding were performed at the same time during World War II and the subsequent years. The number of welders increased substantially during the postwar period. Metal-arc welding was the method mostly applied in the first years of welding. Rutile and acidiccoated electrodes were used in the 1940s. In the early 1950 s basic-coated electrodes partly replaced the rutile and acidic-coated electrodes and remained the most frequently used electrode. Gas-shielded welding was employed from the late sixties, initially metal inert-gas and metal active-gas welding. Later, from the mid1970 s on, tungsten inert-gas welding also came into use.

Up until the early 1970s welding was performed almost exclusively on mild steel. During the production of gas carriers, two ships delivered in 1973 and 1974 were equipped with tanks consisting of $9 \%$ nickel steel. This steel contained no more than $0.2 \%$ chromium. Three ships (1975-1977) were equipped with aluminum tanks. Welding on stainless steel became more and more common during this period, particularly in pipe welding. Stainless steel welding is now widely applied at the yard. However, up to 1973-1974, there had been virtually no stainless steel welding at the shipyard.

\section{Environmental monitoring}

In 1973 a survey of welding fume exposure was undertaken, initiated by concern about the untoward health effects of exposure to nickel-containing welding fumes. The chromium and nickel content of the deposit was not known, but the welding wire that was most frequently used contained $70 \%$ nickel and $13 \%$ chromium. Nine welders using metal-arc or metal inertgas techniques on steel with a content of $9 \%$ nickel were monitored for one week. The total welding fume concentration and the nickel and chromium content of the fumes was measured with personal samples. Welding was performed at the docks (in gas carrier tanks), in the plate and pipe shops, and in open and confined spaces.

Total fume concentrations ranged from 3.6 to $23.6 \mathrm{mg} / \mathrm{m}^{3}$, taken as weekly means, with $7.3 \mathrm{mg} / \mathrm{m}^{3}$ as the median value for all the welders. No correlation was found between the fume concentration and the place of work. The concentrations of nickel were between 0.11 and 1.97 (median 0.43 ) $\mathrm{mg} / \mathrm{m}^{3}$, and the total chromium content ranged from 0.03 to 0.65 (median 0.12 ) $\mathrm{mg} / \mathrm{m}^{3}$. An analysis for hexavalent chromium was not carried out. No measurements were available for earlier periods.

\section{Ventilation and personal protection}

In the 1940s there was a system for leading fresh air passively into confined spaces during welding at the docks. This system was replaced with fans in the 1950s. In the beginning the welders used dust masks made of felt and later switched to carbon filters. After exhaust ventilation was provided at the docks from the mid1960 s on, the conditions improved markedly. Personal respiratory protection and exhaust ventilation were provided in the shops in the early 1970s.

Workers who regularly worked in the vicinity of a welder were also exposed to welding fumes, but at lower concentrations. These workers mainly included pipe fitters (who performed some welding themselves), shipwrights, burners (also exposed to fumes from acetylene cutting), and their helpers and apprentices.

\section{Use of asbestos}

Asbestos was used at the yard until the early 1970s for insulating in machine rooms and for personal protection. Chrysotile was almost exclusively used. All insulating work with asbestos was carried out by the yard's own employees until the late 1960s, when an outside firm was engaged to insulate the new ships. In ships under repair asbestos was removed by the boilermakers and, to some extent, by pipe fitters, mechanics, welders, shipwrights, and by their helpers and apprentices. Some asbestos was removed in the workshops, especially in the pipe shop. Insulation was mainly performed by the boilermakers and, to some extent, by pipe fitters. Boilers and pipes were covered with asbestos plates, and the joints were filled with asbestos powder mixed with a binding agent. This mixture was made on the spot and generated substantial amounts of dust.

Measurements of asbestos dust concentrations from the period of interest were not available. Presumably the docks have been the area most contaminated by asbestos, followed by the pipe shop.

\section{Use of primers}

In general the steel was initially unprimed. However, lead (not lead chromate) was applied to some extent. Zinc chromate was introduced for priming ship shells at the docks in the mid-1950s, and the application was performed by painters and dock workers. Some welding was performed on these primed shells. Iron-based primers were introduced in the 1960s and coincided with the priming being performed before the steel plates entered the shops for cutting and assembly work. Zinc has also been a fume constituent in the occasional welding of galvanized steel.

\section{Subjects and methods}

The personnel register was used for compiling the list of names of the employees at the shipyard. The regis- 
ter was established in 1944-1945 and included both employees working at that time and new workers. For the present study data on all employees with an employment time exceeding three months were collected. The following information was obtained from the register: name, address, date of birth, personal identification number if known, dates for starting and terminating work, and job titles for all employment periods. Information on employment was complete until 31 August 1987.

Information was obtained on 6239 workers. Five were excluded due to missing names or date of birth. The study was restricted to men who were first employed at the shipyard between 1 January 1946 and 31 December 1976, leaving 4887 eligible for further analysis. The starting date of 1 January 1946 wàs chosen because it coincided both with the establishment of an informative personnel register, which is currently in use, and the introduction of welding at the yard. The closing date of 31 December 1976 allows for a minimum assumed development time for cancer of at least 10 years for all participants.

The 153 female workers were excluded, as were 41 foreigners no longer resident in the country, and 24 workers who were deceased or had emigrated before the establishment of the Cancer Registry in 1953. Those 126 who had emigrated after 1 January 1953 were considered to be under follow-up until their date of emigration. Only $44(0.9 \%)$ of the eligible subjects could not be traced. The formation of the cohort is shown in table 1 .

Retired workers, including a former administrator from the personnel office, were temporarily engaged to evaluate the quality of the personnel register with respect to job titles and approximate dates of employment. Job titles had changed during the study period. With the assistance of these retirees' thorough knowledge of previous work conditions, the diversity of job titles in the register could be limited to 32 . The inclusion criteria were set and the assignment of workers to the final job titles was completed before the data on health status were collected.

On the basis of common exposures at the study plant, all job titles were merged into 10 different occupational categories. These categories contribute more person-years than the single job titles and thus provide a more robust basis for estimating an expected incidence of cancer. The occupational categories and job titles were as follows: welders; metal workers, occasionally welding (caulker burners, pipe fitters, coppersmiths); metal workers, seldom or never welding (shipwrights, riveters, boilermakers, grinders, blacksmiths); machine shop workers (mechanics, turners, filers); carpenters (carpenters, joiners, pattern makers); dock workers (laborers, scaffolders, dock workers); sandblasters and painters; assistants and apprentices; office and administrative personnel; and others (transport workers, guards, dustmen, storemen, crane operators, foremen, tool makers, welding supervisors, electricians).

The Cancer Registry of Norway has recorded all new cases of cancer since 1 January 1953 . The registration is more than $99 \%$ complete. In the present study the incidence of cancer among the national male population serves as a reference entity. The expected number of selected cancers was estimated with the use of national five-year age-specific incidence rates for each year from 1953 to 1986 . Events occurring between 1946 to 1952 were not available. Each worker was under observation from the beginning of 1953 or, if he was first employed at a later date, from the middle of the year he was first employed until the occurrence of death, emigration, or the end of follow-up.

Several workers had held more than one job at the yard. All calculations were made with each occupational category being viewed as a separate entity. Thus one worker may have contributed an observed cancer to more than one occupational category, but not more than once within each category or when the incidence of cancer of the total cohort was considered.

Confidence intervals were estimated on the assumption of a Poisson distribution of events with the use of a two-sided test of significance.

\section{Results}

There were 716 deaths from all causes in the cohort versus 681.3 expected, and 252 cases of cancer were observed versus 244.1 expected (table 2).

Fifty-three cases of lung cancer were observed in the whole cohort against 31.3 expected, which is statistically significant at the $99 \%$ level (table 2). The incidence of bladder cancer was also elevated, 22 cases versus 15.2 expected. The number of observed cases of colon cancer was significantly lower than expected (observed 8 , expected 17.9), but the difference was less apparent when cancers of the colon and rectum were merged (observed 24, expected 30.2 ). There was also a deficit of stomach cancer (observed 14, expected 22.1).

Table 1. Formation of the cohort.

\begin{tabular}{|c|c|c|}
\hline & & $N$ \\
\hline Initial numbers of personal records & & 6239 \\
\hline $\begin{array}{l}\text { Incomplete data } \\
\text { Women } \\
\text { Men employed before } 1 \text { January } 1946 \text { or } \\
\text { after } 31 \text { December } 1976\end{array}$ & $\begin{array}{r}5 \\
153 \\
1194\end{array}$ & \\
\hline $\begin{array}{l}\text { Men employed between } 1 \text { January } 1946 \\
\text { and } 31 \text { December } 1976\end{array}$ & & 4887 \\
\hline $\begin{array}{l}\text { Foreigners } \\
\text { Dead or emigrated before } 1 \text { January } 1953 \\
\text { Unidentified }\end{array}$ & $\begin{array}{l}41 \\
24 \\
44\end{array}$ & \\
\hline Ultimate cohort & & 4778 \\
\hline
\end{tabular}


Table 2. Observed and expected cases of cancer at selected sites and total mortality due to cancer among shipyard workers. $($ SIR $=$ standardized incidence ratio, $95 \% \mathrm{Cl}=95 \%$ confidence interval)

\begin{tabular}{lrrcc}
\hline Cancer site $^{\mathrm{a}}$ & Observed & Expected & SIR & $95 \% \mathrm{CI}$ \\
\hline Stomach (151) & 14 & 22.1 & 63 & $35-106$ \\
Colon (153) & 8 & 17.9 & $45^{*}$ & $20-89$ \\
Rectum (154) & 16 & 12.3 & 130 & $74-211$ \\
Nose (160) & 2 & 1.0 & 211 & $21-758$ \\
Larynx (161) & 6 & 3.6 & 167 & $61-364$ \\
Lung (162) & 53 & 31.3 & $169^{* *}$ & $127-217$ \\
Mesothelioma (163) & 2 & 0.7 & 267 & $27-960$ \\
Kidney (180) & 5 & 9.6 & 52 & $17-121$ \\
Bladder (181) & 22 & 15.2 & 145 & $91-220$ \\
All cancer (140-204) & 252 & 244.1 & 103 & $90-116$ \\
\hline
\end{tabular}

a Code of the International Classification of Diseases (seventh revision) in parentheses

* $P<0.05,{ }^{*} * P<0.01$.
Two cases of malignant mesothelioma had occurred (expected 0.7), one in a turner employed in 1946 for less than one year and one in a shipwright employed from 1950 to 1965 . The time between first employment at the yard and the occurrence of cancer was 34 and 35 years, respectively.

Lung cancer was in excess in several occupational categories (table 3 ). The excess was statistically significant among the machine shop workers (observed 8, expected 2.9) and among the assistants and apprentices (observed 38, expected 19.2). As most of the workers started out as unskilled, this latter group comprises three-fourths of the entire cohort. Therefore, for all types of cancer, the results of this group closely resem-

Table 3. Observed and expected cases of lung cancer [code 162 of the International Classification of Diseases (seventh revision)] among the shipyard workers according to their occupational category. (SIR = standardized incidence ratio, $95 \% \mathrm{Cl}=95 \%$ confidence interval)

\begin{tabular}{|c|c|c|c|c|c|c|}
\hline $\begin{array}{l}\text { Occupational } \\
\text { category }\end{array}$ & $\begin{array}{c}\text { Number } \\
\text { of } \\
\text { workers }\end{array}$ & Observed & Expected & SIR & $95 \% \mathrm{Cl}$ & $\begin{array}{l}\text { Person-years } \\
(1953-1986)\end{array}$ \\
\hline Welders & 783 & 7 & 3.2 & 221 & $88-454$ & 15807.0 \\
\hline Metal workers occasionally welding & 244 & 1 & 1.8 & 57 & --316 & 5583.0 \\
\hline Metal workers seldom/never welding & 722 & 6 & 2.8 & 214 & $79-468$ & 16460.0 \\
\hline Machine shop workers & 279 & 8 & 2.9 & $276^{*}$ & $121-545$ & 7384.5 \\
\hline Carpenters & 105 & - & 1.3 & & & 2652.0 \\
\hline Dock workers & 253 & 7 & 3.3 & 210 & $84-432$ & 5754.0 \\
\hline Sandblasters, painters & 43 & - & 0.4 & & & 898.5 \\
\hline Assistants and apprentices & 3610 & 38 & 19.2 & $198^{\star \star}$ & $140-272$ & 84892.0 \\
\hline Office and administrative workers & 304 & - & 1.2 & . & & 6597.5 \\
\hline Others & 684 & 7 & 6.4 & 109 & $44-224$ & 16566.5 \\
\hline Total & 4778 & 53 & 31.3 & $169^{* *}$ & $127-217$ & 110407.0 \\
\hline
\end{tabular}

${ }^{*} \mathrm{P}<0.05,{ }^{* *} \mathrm{P}<0.01$.

Table 4. Observed and expected cases of cancer at selected sites among the shipyard workers according to their occupational category.

\begin{tabular}{|c|c|c|c|c|c|c|c|c|c|c|c|c|}
\hline \multirow{3}{*}{$\begin{array}{l}\text { Occupational } \\
\text { category }\end{array}$} & \multicolumn{12}{|c|}{ Cancer site } \\
\hline & \multicolumn{2}{|c|}{ Stomach } & \multicolumn{2}{|c|}{ Colon } & \multicolumn{2}{|c|}{ Rectum } & \multicolumn{2}{|c|}{ Kidney } & \multicolumn{2}{|c|}{ Bladder } & \multicolumn{2}{|c|}{ All sites } \\
\hline & $\begin{array}{l}\text { Ob- } \\
\text { served }\end{array}$ & $\begin{array}{c}\text { Ex- } \\
\text { pected }\end{array}$ & $\begin{array}{l}\text { Ob- } \\
\text { served }\end{array}$ & $\begin{array}{c}\text { Ex- } \\
\text { pected }\end{array}$ & $\begin{array}{l}\text { Ob- } \\
\text { served }\end{array}$ & $\begin{array}{c}\text { Ex- } \\
\text { pected }\end{array}$ & $\begin{array}{l}\text { Ob- } \\
\text { served }\end{array}$ & $\begin{array}{c}\text { Ex- } \\
\text { pected }\end{array}$ & $\begin{array}{l}\text { Ob- } \\
\text { served }\end{array}$ & $\begin{array}{c}\text { Ex- } \\
\text { pected }\end{array}$ & $\begin{array}{l}\text { Ob- } \\
\text { served }\end{array}$ & $\begin{array}{c}\text { Ex- } \\
\text { pected }\end{array}$ \\
\hline Welders & 1 & 1.8 & 2 & 1.7 & 1 & 1.2 & - & 1.0 & 2 & 1.5 & 30 & 24.5 \\
\hline $\begin{array}{l}\text { Metal workers } \\
\text { occasionally welding }\end{array}$ & 1 & 1.2 & 1 & 1.0 & 2 & 0.7 & - & 0.5 & 1 & 0.9 & 12 & 13.6 \\
\hline $\begin{array}{l}\text { Metal workers } \\
\text { seldom or never } \\
\text { welding }\end{array}$ & 1 & 1.8 & 1 & 1.6 & 1 & 1.1 & 1 & 0.9 & 4 & 1.3 & 28 & 22.9 \\
\hline Machine shop workers & 2 & 2.5 & - & 1.8 & 0 & 1.2 & 1 & 0.9 & 1 & 1.4 & 27 & 23.5 \\
\hline Carpenters & 3 & 1.1 & - & 0.8 & 0 & 0.5 & 1 & 0.4 & - & 0.6 & 6 & 10.0 \\
\hline Dock workers & 1 & 2.8 & 2 & 2.0 & $5^{*}$ & 1.3 & - & 1.0 & 3 & 1.7 & 31 & 26.0 \\
\hline Sandblasters, painters & 1 & 0.3 & - & 0.2 & 0 & 0.2 & - & 0.1 & - & 0.2 & 1 & 3.0 \\
\hline $\begin{array}{l}\text { Assistants and } \\
\text { apprentices }\end{array}$ & 6 & 12.4 & $2^{\star \star}$ & 10.7 & 10 & 7.4 & 2 & 6.1 & 15 & 9.1 & 166 & 149.7 \\
\hline $\begin{array}{l}\text { Office and adminis- } \\
\text { trative workers }\end{array}$ & - & 0.7 & 1 & 0.7 & 0 & 0.5 & - & 0.4 & 1 & 0.6 & 9 & 9.6 \\
\hline Others & - $^{*}$ & 4.6 & 3 & 3.7 & 2 & 2.5 & 1 & 1.9 & 6 & 3.2 & 45 & 48.9 \\
\hline Total & 14 & 22.1 & $8^{*}$ & 17.9 & 16 & 12.3 & 5 & 9.6 & 22 & 15.2 & 252 & 244.1 \\
\hline
\end{tabular}

${ }^{*} \mathrm{P}<0.05,{ }^{* *} \mathrm{P}<0.01$. 
bled those of the total cohort. High standardized incidence ratios for lung cancer were also found among the welders (observed 7, expected 3.2), the metal workers welding only rarely, and the dock workers.

The excess incidence of lung cancer was the most pronounced among the shipyard workers first employed in 1950-1959 (observed 27, expected 13.0, $\mathrm{P}<0.01$ ) and in 1960-1969 (observed 8, expected 3.1, $\mathrm{P}<0.05$ ). The eight cases of lung cancer found among the machine shop workers had all occurred in workers first employed before 1960 . There was no cluster of lung cancer cases by period of employment in the subcohort of welders.

Table 4 shows the incidence of cancer at selected sites by occupational category. There was no statistically significant variation in risk for any cancer site between occupational groups, with the exception of a statistically significant excess of cancer of the rectum among dock workers. However, when cancer of the rectum was merged with cancer of the colon, the persistent excess was no longer significant (observed 7 , expected 3.3). A deficit of colon cancer was only seen among the assistants and apprentices. For cancer of the blad- der, the standardized incidence ratio (SIR) was nonsignificantly increased among the metal workers rarely welding (observed 4, expected 1.3). No statistically significant excess or deficit of cancer in all sites was found in any occupational category.

To allow for different presumed development times for cancer, analyses were performed according to time since first employment. The incidence of lung cancer and cancer of the bladder in the whole cohort was significantly increased 10 years and more after first employment in the yard. Seven of the eight lung cancers among the machine shop workers occurred 20 years or more after first employment.

In table 5 the cohort has been stratified according to total length of employment, and table 6 shows the incidence of lung cancer by duration of employment in selected occupational categories. A presumed 10-year development time is simulated by the exclusion of person-years until 10 years after first employment. There was no significant trend in risk with duration of employment for any cancer site except lung cancer (table 5). The excess incidence of lung cancer was the most pronounced for workers employed for

Table 5. Observed and expected cases of cancer at selected sites among the shipyard workers according to length of employment. A latency period of 10 years has been accounted for. (SIR $=$ standardized incidence ratio, $95 \% \mathrm{Cl}=95 \%$ confidence interval)

\begin{tabular}{|c|c|c|c|c|c|c|c|c|c|c|c|c|c|c|c|c|}
\hline \multirow{3}{*}{ Cancer site ${ }^{3}$} & \multicolumn{16}{|c|}{ Length of employment } \\
\hline & \multicolumn{4}{|c|}{$<1$ year } & \multicolumn{4}{|c|}{$1-5$ years } & \multicolumn{4}{|c|}{$>5$ years } & \multicolumn{4}{|c|}{ Total } \\
\hline & $\begin{array}{c}\text { Ob- } \\
\text { served }\end{array}$ & $\begin{array}{c}\text { Ex- } \\
\text { pected }\end{array}$ & SIR & $95 \% \mathrm{Cl}$ & $\begin{array}{l}\text { Ob- } \\
\text { served }\end{array}$ & $\begin{array}{c}\text { Ex- } \\
\text { pected }\end{array}$ & SIR & $95 \% \mathrm{Cl}$ & $\begin{array}{c}\text { Ob- } \\
\text { served }\end{array}$ & $\begin{array}{c}\text { Ex- } \\
\text { pected }\end{array}$ & SIR & $95 \% \mathrm{Cl}$ & $\begin{array}{c}\text { Ob- } \\
\text { served }\end{array}$ & $\begin{array}{c}\text { Ex- } \\
\text { pected }\end{array}$ & SIR & $95 \% \mathrm{Cl}$ \\
\hline $\begin{array}{l}\text { Stomach (151) } \\
\text { Colon (153) } \\
\text { Rectum (154) } \\
\text { Nose (160) } \\
\text { Larynx (161) } \\
\text { Lung (162) } \\
\text { Kidney (180) } \\
\text { Bladder (181) }\end{array}$ & $\begin{array}{r}4 \\
3 \\
2 \\
1 \\
21 \\
-4\end{array}$ & $\begin{array}{l}4.8 \\
1.2 \\
2.9 \\
0.2 \\
0.9 \\
7.5 \\
2.3 \\
3.6\end{array}$ & $\begin{array}{c}33 \\
\dot{1} \\
104 \\
918 \\
106 \\
280^{*} \\
\dot{1} \\
112\end{array}$ & $\begin{array}{c}23-213 \\
21-303 \\
100-3600 \\
\overline{1}-411 \\
173-428 \\
\cdot \cdot 283\end{array}$ & $\begin{array}{r}3 \\
1 \\
5 \\
2 \\
14 \\
3 \\
7\end{array}$ & $\begin{array}{l}5.7 \\
5.0 \\
3.5 \\
0.3 \\
1.1 \\
9.1 \\
2.8 \\
4.4\end{array}$ & $\begin{array}{r}52 \\
20 \\
141 \\
\cdot \\
191 \\
154 \\
108 \\
160\end{array}$ & $\begin{array}{r}11-154 \\
-112 \\
46-334 \\
\cdot \\
18-655 \\
85-258 \\
21-314 \\
64-327\end{array}$ & $\begin{array}{r}6 \\
6 \\
8 \\
-3 \\
15 \\
1 \\
11\end{array}$ & $\begin{array}{r}8.6 \\
7.2 \\
5.0 \\
0.4 \\
1.4 \\
12.6 \\
3.8 \\
6.3 \\
6.3\end{array}$ & $\begin{array}{r}70 \\
83 \\
159 \\
\cdot \\
213 \\
119 \\
27 \\
175\end{array}$ & $\begin{array}{r}26-152 \\
31-182 \\
70-316 \\
\cdot \\
43-629 \\
67-196 \\
-147 \\
87-313\end{array}$ & $\begin{array}{r}13 \\
7 \\
16 \\
2 \\
6 \\
50 \\
50 \\
4 \\
22\end{array}$ & $\begin{array}{r}19.1 \\
13.4 \\
11.4 \\
0.9 \\
3.4 \\
29.2 \\
8.9 \\
14.3\end{array}$ & $\begin{array}{r}68 \\
52 \\
140 \\
222 \\
178 \\
171^{\star} \\
45 \\
154\end{array}$ & $\begin{array}{r}36-116 \\
21-108 \\
80-228 \\
22-800 \\
65-385 \\
127-226 \\
12-115 \\
97-233\end{array}$ \\
\hline $\begin{array}{l}\text { All cancer } \\
(140-204)\end{array}$ & 67 & 54.6 & 123 & $95-156$ & 62 & 66.8 & 93 & $71-119$ & 103 & 94.6 & 109 & $88-131$ & 232 & 216.0 & 107 & $94-122$ \\
\hline
\end{tabular}

a Code of the International Classification of Diseases (seventh revision) in parentheses.

- $\mathrm{P}<0.01$.

Table 6. Observed and expected cases of lung cancer [code 162 of the International Classification of Diseases (seventh revision)] for selected occupational categories according to length of employment in the selected category only. A latency period of 10 years has been accounted for.

\begin{tabular}{|c|c|c|c|c|c|c|c|c|}
\hline \multirow{3}{*}{$\begin{array}{l}\text { Occupational } \\
\text { category }\end{array}$} & \multicolumn{8}{|c|}{ Length of employment } \\
\hline & \multicolumn{2}{|c|}{$<1$ year } & \multicolumn{2}{|c|}{$1-5$ years } & \multicolumn{2}{|c|}{$>5$ years } & \multicolumn{2}{|c|}{ Total } \\
\hline & Observed & Expected & Observed & Expected & Observed & Expected & Observed & Expected \\
\hline Welders & - & 0.4 & $5^{\star *}$ & 0.9 & 1 & 1.7 & 6 & 2.9 \\
\hline $\begin{array}{l}\text { Metal workers } \\
\text { occasionally welding }\end{array}$ & - & 0.1 & - & 0.3 & 1 & 1.3 & 1 & 1.7 \\
\hline $\begin{array}{l}\text { Metal workers seldom } \\
\text { or never welding }\end{array}$ & 1 & 0.5 & 1 & 0.7 & 3 & 1.5 & 5 & 2.6 \\
\hline Machine shop workers & 2 & 0.8 & $4^{*}$ & 0.8 & 2 & 1.1 & $8^{*}$ & 2.7 \\
\hline Dock workers & $4^{*}$ & 0.8 & 2 & 1.3 & 1 & 1.0 & 7 & 3.1 \\
\hline $\begin{array}{l}\text { Assistants and } \\
\text { apprentices }\end{array}$ & $18^{* *}$ & 6.3 & 13 & 8.8 & 5 & 3.0 & $36^{* \star}$ & 18.0 \\
\hline
\end{tabular}

* $P<0.05$, * $P<0.01$. 
less than one year (observed 21, expected 7.5, SIR 280), and the standardized incidence ratio decreased to 119 for workers employed for more than five years (table 5). The majority of these short-time employees had been engaged as assistants or apprentices (observed 18, expected 6.3), and the excess was also significantly elevated among the short-time dock workers (observed 4 , expected 0.8 ) (table 6). For employees with a duration of employment of one to five years there was a statistically significant excess of lung cancer among the welders (observed 5, expected 0.9) and the machine shop workers (observed 4 , expected 0.8 ). The incidence of cancers of the colon and rectum was marginally increased among the workers employed for more than five years (observed 14, expected 12.2) (table 5).

\section{Discussion}

In the present study an observed case of cancer was ascribed to an occupational category when a worker had at least three months of employment in one of the jobs constituting the category. Assignment to one category was independent of employment in another job at a different period of time at the yard. One worker may thus have contributed with a cancer case in more than one occupational category. With the use of this method the observations within the categories were not diluted by the pooling of the worker's total experience into one category only, and the observed number of cases in each category is a true representation of the cancers that may have occurred as a result of work exposure in the category at issue.

The personnel register was the only source of information about each worker. Current use of the register and the fact that it was established comparatively late gives us reason to trust its completeness. The files on former employees have been kept fully independent of the reasons each one had for terminating work, and this practice implies that a possible loss of personnel cards has not been dependent on outcome of illness or death. As the register contained a substantial number of files on workers employed for less than three months, we have no reason to believe that there is any deficit of short-time employees in the cohort.

As a result of the control and corrections of the individual personnel cards by former employees, misclassification of workers by the job title given in the personnel register seems unlikely.

Only $44(0.9 \%)$ of the workers were lost to followup. Twenty-nine of these were assistants or apprentices. Only 15 skilled workers were not traced. These 15 unidentified workers were scattered among several occupational categories; hence a possible outcome dependency of the loss will have had very little influence on the results. With respect to the emigrants it is unlikely that the outcome under study has had any bearing on the decision to go abroad.
A primary positive selection of workers may have affected the cohort at its inception, and this phenomenon could have concealed a possible association between work-related exposure and illness. However, its impact on the incidence of cancer is assumed to be limited. In some of the analyses a presumed "latency period" of 10 years from first date of employment in an occupational category was accounted for. Consequently, these effect estimates have not been attenuated by work experience etiologically unrelated to exposure in the job or jobs at issue $(23,24)$.

The main finding of the present study was an excess incidence of lung cancer in the total cohort of shipyard workers (SIR 169). The magnitude of the excess was higher than that reported in some epidemiologic studies on shipyard employees $(9,17,20)$, while other authors have demonstrated an approximately twofold risk of lung cancer for shipyard workers $(19,21,22)$.

Exposure to asbestos is likely to explain part of the excess of lung cancer found in this cohort. The demonstration of an increased incidence of lung cancer in several occupational categories at the shipyard is in accordance with the results of other investigations $(9,17$, $18,20,21)$. However, the results from these studies are inconsistent as to which occupational groups had an excess of asbestos-related cancers, probably due to diverse routines for asbestos handling or possibly to methodological shortcomings.

At the shipyard, asbestos had been handled mainly by the boilermakers, but also to some extent by the pipe fitters, mechanics, welders, and shipwrights. Bystander exposure was common, and the docks was probably the area where most of the asbestos was handled. As might be expected, an increased incidence of lung cancer was found among the machine shop workers, dock workers, metal workers who rarely welded (including boilermakers and shipwrights), and welders. Exposure to zinc chromate primer might have been a minor additional causal factor among the dock workers (25).

The overall standardized incidence ratio for lung cancer among the welders did not exceed the corresponding standardized incidence ratio of the other occupational categories. The mean age at employment and the secular distribution of person-years were not so different as to invalidate tentative internal comparisons. Five lung cancers versus 0.9 expected occurred in the subcohort with $1-5$ years of employment (table 6). Although this excess was highly significant, the result is difficult to interpret as there was no excess of lung cancer among the welders employed at the shipyard for more than five years. The extent to which possible previous welding experience at other shipyards or in other industries has influenced the results is not known for the different welder subcohorts.

There was no excess of lung cancer among the workers assigned to the category of metal workers occasionally welding (table 4). The pipe fitters, who had also been exposed to some extent to asbestos, constituted 
a great proportion of these workers. The result cannot be explained in terms of variation in age at first employment or by the secular distribution of personyears. With only 1.8 cases expected, the result is hampered by considerable uncertainty.

The excess incidence of lung cancer in the total cohort decreased as the length of employment increased and was significant only for the workers employed for less than one year (table 6). The excess of lung cancer among the short-term workers was the most evident among the assistants and apprentices, who formed a homogeneous group before the education of apprentices was properly organized in the early 1960s. A substantial number of these short-time employees had not been engaged in other jobs at the shipyard. These workers thus contributed several lung cancer cases to the overall excess. It is likely that this group of unskilled workers exhibits an increased lung cancer risk which may be related both to individual disease determinants and to exposure factors at other workplaces. For skilled workers the excess of lung cancer was the most prominent for the workers with a duration of employment of one to five years. These results focus on the possibility of smoking acting as an important confounder in this study. However, no information was available on the smoking habits of the present cohort.

In 1964-1965 a survey of smoking habits was performed in the 1893-1927 Norwegian birth cohort (26). The percentage of current plus previous smokers was $77.6 \%$. Industrial workers exhibited a prevalence of $82 \%$ versus $85 \%$ for office and administrative employees. According to the method described by Axelson (27), the degree of confounding determined on the basis of these numbers with regard to lung cancer caused by smoking alone amounts to a maximum standardized incidence ratio of 110 . A standardized incidence ratio of about 170 would correspond to a percentage of nonsmokers among the reference population and the shipyard employees of 50 and 20, respectively. In the present study such a difference seems unlikely.

The Axelson method (27) does not account for duration of smoking and lifetime consumption of tobacco. The uncertainties in applying the 1964-1965 survey of smoking (26) to the present shipyard cohort also preclude firm conclusions concerning the contribution of smoking to the lung cancer excess in the different subgroups.

Lung cancer rates in some other European countries (eg, Great Britain) are three times as high as in Norway. The lung cancer rate of workers employed for less than one year was thus similar to that of an average British man. Differences in smoking could in fact account for larger differences in lung cancer rates in Norway than in most other western European countries.

Two cases of mesothelioma were observed against 0.7 expected. When judging the expected figures, one has to take into consideration that the figures for the general population are to a great extent due to asbestos exposure. There is consistent evidence that exposure to chrysotile, which may have occurred in the present cohort, is associated with a smaller risk of mesothelioma than is exposure to amphiboles (28). As the estimated mean development time is about 30 to 35 years, the observation period in the present study may be too short to reveal a possible excess. The small numbers preclude further interpretation.

In relation to the observed deficit of kidney cancer (table 4), it should be noted that the regional figures for the incidence of this tumor are low. The part of the country where the shipyard is located had a deficit of $29 \%$ of kidney cancer in the period 1966-1975 compared with the national incidence (29).

The deficit of stomach cancer may also partly be explained by regional variations in the incidence of cancer. The incidence of stomach cancer in the part of the country where the shipyard is located was $14 \%$ lower than the national figures in the period 1966 1975 (29).

The excess incidence of cancer of the bladder (table 4 ) is difficult to interpret in terms of occupational exposure, and is suggestive of smoking acting as a confounder in this study. Exposure to asbestos and tobacco smoking may explain the excess of larynx cancer (table 5), but with only six cases observed the result may be due to chance.

It is unlikely that exposure to welding fumes constitutes a major lung cancer hazard in the present study, but a small excess of lung cancer caused by welding fume exposure may well be present in the figures. Further follow-up with identification of those exposed to fumes from stainless steel welding from the early 1970s onwards, when also asbestos ceased to be used at the shipyard, is needed to determine whether the excess of lung cancer among the welders is related to stainless steel welding.

\section{Acknowledgments}

This project was financed by Bundesministerium für Forschung und Technologie and the Royal Norwegian Council for Scientific and Industrial Research.

We thank the staff of the shipyard Moss Rosenberg Verft for their cooperation throughout the study, especially Ms IH Halvorsen at the medical office. We warmly thank Mr P Theie and Mr P Berg for their computer assistance, Ms P Flor for her linguistic help, and Ms $\mathrm{K}$ Theie for her typing assistance.

\section{References}

1. Beaumont JJ, Weiss NS. Lung cancer among welders. J Occup Med 1981;23:839-44.

2. Becker N, Claude J, Frentzel-Beyme R. Cancer risk of arc welders exposed to fumes containing chromium and nickel. Scand J Work Environ Health 1985;11:75-82. 
3. Breslow L, Hoaglin L, Rasmussen G, Abrams HK. Occupations and cigarette smoking as factors in lung cancer. Am J Public Health 1954;44:171-81.

4. Lerchen ML, Wiggins CL, Samet JM. Lung cancer and occupation in New Mexico. J Natl Cancer Inst 1987; 79:639-45.

5. Menck HR, Henderson BE. Occupational differences in rates of lung cancer. J Occup Med 1976;18:797-801.

6. Polednak AP. Mortality among welders, including a group exposed to nickel oxides. Arch Environ Health $1981 ; 36: 235-42$.

7. Sjögren B. A retrospective cohort study of mortality among stainless steel welders. Scand J Work Environ Health 1980;6:197-200.

8. Sjögren B, Gustavsson A, Hedström L.. Mortality in two cohorts of welders exposed to high- and low-levels of hexavalent chromium. Scand J Work Environ Health 1987;13:247-51.

9. Tola S, Kalliomäki P-L, Pukkala E, Asp S, Korkala M-L. Incidence of cancer among welders, platers, machinists, and pipe fitters in shipyards and machine shops. Br J Ind Med 1988;45:209-18.

10. Dunn JE, Weir JM. A prospective study of mortality of several occupational groups: special emphasis on lung cancer. Arch Environ Health 1968;17:71--6.

11. Ott M, Holder BB, Langner RR. Determinants of mortality in an industrial population. J Occup Med 1976; 18:171-7.

12. Langărd S. Confounding and effect-modifying factors in epidemiological studies in welders. In: Stern RM, Berlin A, Fletcher AC, Järvisalo J, ed. Proceedings of the international conference on health hazards and biological effects of welding fumes and gases, Copenhagen, 18-21 February, 1985. Amsterdam: Excerpta Medica, 1986:439-43.

13. Peto J. Cancer morbidity and mortality studies of welders. In: Stern RM, Berlin A, Fletcher AC, Järvisalo $\mathrm{J}$, ed. Proceedings of the international conference on health hazards and biological effects of welding fumes and gases, Copenhagen, 18-21 February, 1985. Amsterdam: Excerpta Medica, 1986:423-34.

14. Maxild J, Andersen M, Kiel P, Stern RM. Mutagenicity of fume particles from metal arc welding on stainless steel in the Salmonella/microsome test. Mutat Res 1978; $56: 235-43$.

15. Hansen K, Stern RM. Welding fumes and chromium compounds in cell transformation assays. J Appl Toxicol 1985;5:306-14.

16. Stern RM. Assessment of risk of lung cancer for welders. Arch Environ Health 1983;38:148-55.
17. Beaumont JJ, Weiss NS. Mortality of welders, shipfitters and other metal trades workers in Boilermakers Local no 104, AFL-CIO. Am J Epidemiol 1980;112: $775-86$

18. Blot WJ, Morris LE, Stroube R, Tagnon I, Fraumeni JF. Lung and laryngeal cancers in relation to shipyard employment in costal Virginia. J Natl Cancer Inst 1980; $65: 571-5$.

19. Kolonel LN, Yoshizawa CN, Hirohata T, Myers BC. Cancer occurrence in shipyard workers exposed to asbestos in Hawaii. Cancer Res 1985;45:3924-8.

20. Newhouse ML, Oakes D, Woolley AJ. Mortality of welders and other craftsmen at a shipyard in NE England. $\mathrm{Br} \mathrm{J}$ Ind Med 1985;42:406-10.

21. Puntoni R, Vercelli M, Merlo F, Valerio F, Santi L. Mortality among shipyard workers in Genoa, Italy. Ann NY Acad Sci 1979;330:353-77.

22. Sanden $\AA$, Näslund PE, Järvholm B. Mortality in lung and gastrointestinal cancer among shipyard workers. Int Arch Occup Environ Health 1985;55:277-83.

23. Langård $S$, Andersen AA. Betydningen av bruk av latenstid, kritisk alder og valg av referansepopulasjon ved beregning av cancerinsidens i kohort-studier [The importance of use of latency period, critical age, and choice of reference populations for the estimation of cancer incidence in cohort studies]. In: Arbeidsforskningsinstituttene, 29th Nordic meeting for occupational hygiene. Hønefoss, Norway, 3-5 November 1980. Oslo: Arbeidsforskningsinstituttene, 1980:92.

24. Rothman KJ. Induction and latent periods. Am J Epidemiol 1981;114:253-9.

25. Dalager NA, Mason TJ, Fraumeni JF, Hoover R, Payne WW. Cancer mortality among workers exposed to zinc chromate paints. J Occup Med 1980;22:25-9.

26. Zeiner-Henriksen T. Røkevaner i den norske befolkning [Smoking habits in the Norwegian population]. Tidsskr Nor Lxeforen 1976;96:617-20.

27. Axelson $O$. Aspects on confounding in occupational health epidemiology [Letter to the editor]. Scand J Work Environ Health 1978;4:98-102.

28. Peto J, Doll R, Hermon C, Binns W, Clayton R, Goffe $T$. Relationship of mortality to measures of environmental asbestos pollution in an asbestos textile factory. Ann Occup Hyg 1985;29:305-55.

29. Cancer Registry of Norway. Geographical variations in cancer incidence in Norway 1966 75. Oslo: Cancer Registry of Norway, 1978.

Received for publication: 7 February 1989 